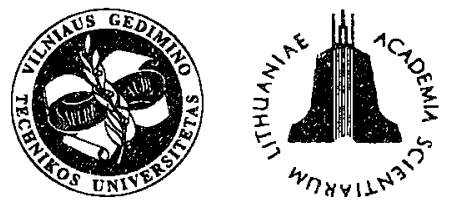

ISSN 1648-4142 TRANSPORT

http:/www.vtu.lt/english/editions

\title{
REALIZATION EFFECTS OF ENFORCING THE EU REGULATION ON THE INSTALLATION OF RECORDING EQUIPMENT IN VEHICLES
}

\author{
Rimas Limba, Jonas Lazauskas \\ Vilnius Gedminas Technical University, Sauletekio al. 11, Lt-2040 Vilnius, Lithuania. \\ E-mail:vidvas@ti.vtu.lt
}

Received 200202 12; accepted 20020418

\begin{abstract}
Preparing to become a member of the European Union Lithuania will have to keep the requirements of the EU Regulation 3821/85 EEC in road transport. It concerns the installation of recording equipment in the vehicles of international transportation and local passenger and freight transport. According to the EU Regulation recording equipment (tachographs) must not be installed in every vehicle and it will be done step by step. About 38 thousand of vehicles will have operating tachographs and for four years it will require about 8 million Lt of investments per year, but the conditions of work and rest of drivers will be improved and the number of accidents will be decreased.
\end{abstract}

Keywords: regulation, tachograph, roads, transport, effects, work, relaxation.

\section{Introduction}

Basic rules of the alternation of work and relaxation and the control of keeping the established order in road transport were determined by the Regulation No 1-1532 "On the Ratification of European States Agreement on Work Regulation of Road Vehicles Bound for the International Routes (AETR)", adopted in Lithuania on September 24 1996, as well as the order No126/44 of the Ministers of Transportation and Governing Reforms and Municipality affairs "On tachographs using rules ratifity", issued on April 25, 2000, as well as the orders No 497 and No 505 of the Minister of Transportation „On Passenger and Freight Transportation Between Various States " [1-3] issued in 1998. These documents determine the schedule of work and relaxation and the control measures in road traffic. In passenger and freight traffic between various states a tachograph, i.e. a device for recording work and leisure hours is used, while on the local routes a tachograph or a $\log$ book may be chosen. To harmonize the Lithuanian documents with the EU regulation $3821 / 85$ (the regulation $2135 / 98$ only added), the use of tachographs will be introduced on the local routes as well. The major objective of introducing these recording devices in transport is to improve the conditions of work of vehicle operators as well as safety on the road.

According to the regulation $3821 / 85 /$ EEC, tachographs should be installed in trucks and buses $[2,4,5]$.

\section{The Expenses of Vehicle Operators due to More Exten- sive Application of Tachographs}

The analysis was based on the data provided by the joint-stock company „Regitra“, Lithuanian Free Market Institute researches, with some correlational corrections made, which would allow more accurate evaluation of the actual state of road transportation and transport facilities $[4,6-9]$.

The actual situation in this area (more than 70 thous. units) is as follows (Fig 1):

1. In some vehicles tachographs have been installed but not used, since it is not required in Lithuania;

2. Other transport facilities are employed without tachographs.

It has been stated that in fact now, about 37,8 thous. of transport facilities are in actual service in which tachographs will have to be used when the above regulation comes into force with all detailed requirements. About $38 \%$ of these vehicles have tachographs installed, which means that these devices should be installed in 22.8 thous. of vehicles in addition to those already provided with them. An average cost of a tachograph (including its installation and maintenance costs and taking into account the availibility of second - hand units) is 1.5 thous. $\mathrm{Lt}$; the cost of 100 tachograms is $14 \mathrm{Lt}$; the number of working days a year -253 ; drivers' rotation coefficient -1.2 ; inspection every 2 years - 200Lt; other maintenance costs make $10 \%$ of the total maintenance costs per year.

To install tachographs in 22.8 thous. more vehicles would require the investment of 22.1 million $\mathrm{Lt}$ at a time. The inspection of tachographs (once in 2 years) and maintenance costs for 37.8 thous. of vehicles (i.e. tachograms, other expenses) would come up to 3.7 million Lt (Table 1 3).

The devices in 220 vehicles per month now can be 
installed. Therefore, installing tachographs in 15.8 thous. of vehicles would take about 5 years.

The research of the readiness of operators to install the devices allows us to assume that when the regulation $3821 / 85 /$ EEC comes into force, tachographs will be operated in 17.7 thous. of vehicles [9]. Out of this number, 6.0 thous. of transport facilities will be equipped with tachographs, in addition to those already provided with them. The installation of the devices in 6.0 thous. more vehicles would require 7.6 million Lt per year.

Obligatory checking of tachographs (each 2 year) and maintenance costs for 17.7 thous. of vehicles will be about 2.4 million Lt per year (Tables 4 - 6).

The installation of additional tachometers will mostly affect the sectors of transportation (physical persons and road transport) agriculture and associated services (Fig 2).

The operators of transport facilities suggest introducing a transition period fill 1 January 2006 for tachograph installation.

The additional expenses due to compulsory installation of tachographs and their operation will not be im-

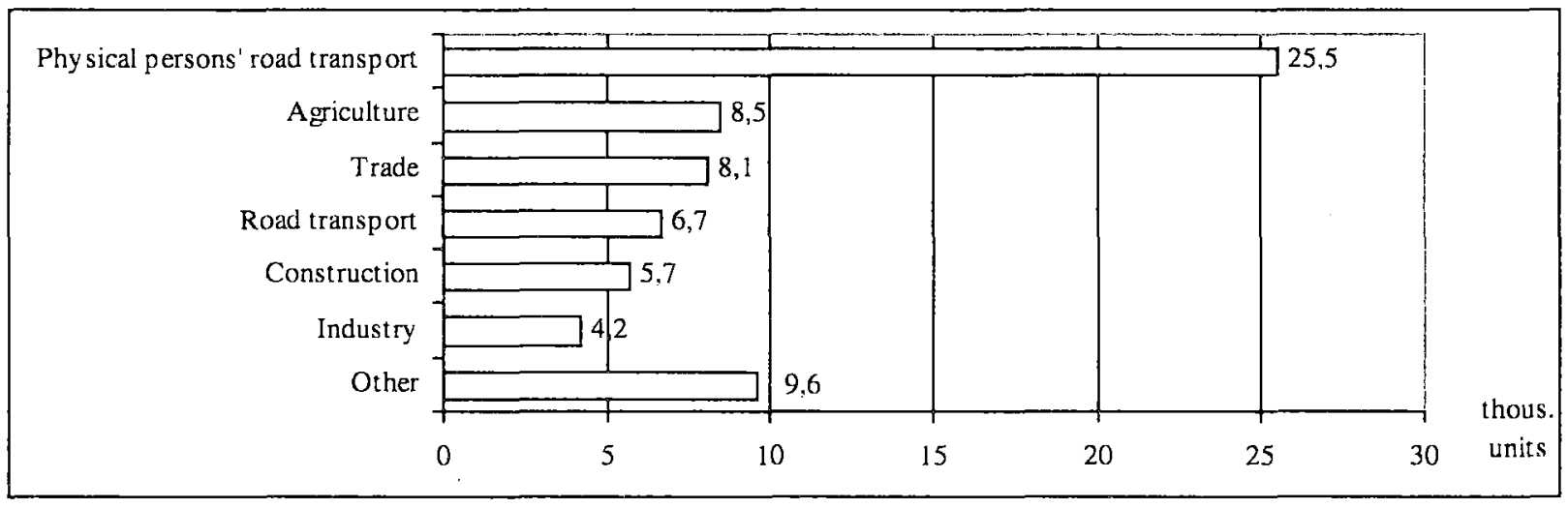

Fig 1. Transport facilities registered in Lithuania in which tachographs have to be employed

Table 1. Vehicles in service in which tachographs will have to be used when the regulation comes in force

\begin{tabular}{|l|c|c|}
\hline Type of a vehicle and ownership & $\begin{array}{c}\text { With tachographs installed } \\
\text { (thous. units) }\end{array}$ & Without tachographs (thous. units) \\
\hline Freight vehicle (juridical person) & 10.9 & 13.8 \\
\hline Freight vehicle (physical person) & 1.8 & 6.3 \\
\hline Buses (juridical person) & 2.3 & 2.7 \\
\hline Total: & 15.0 & 22.8 \\
\hline
\end{tabular}

Table 2. Costs of installing tachographs in 22.8 thous. of vehicles in service

\begin{tabular}{|l|c|}
\hline \multicolumn{1}{|c|}{ Type of a vehicle and ownership } & Cost of Tachograph Installation (millions Li) \\
\hline Freight vehicle (juridical person) & 13.2 \\
\hline Freight vehicle (physical person) & 7.9 \\
\hline Buses (juridical person) & 1.0 \\
\hline \multicolumn{1}{|c|}{ Total: } & 22.1 \\
\hline
\end{tabular}

Table 3. Maintenance costs of tachographs of 37.8 thous. vehicles per year

\begin{tabular}{|l|c|}
\hline Type of a vehicle and ownership & Maintenance costs of tachographs per year (million Lt) \\
\hline Freight vehicle (juridical person) & 2.6 \\
\hline Freight vehicle (physical person) & 1.0 \\
\hline Buses (juridical person) & 0.1 \\
\hline \multicolumn{1}{|c|}{ Total: } & $\mathbf{3 . 7}$ \\
\hline
\end{tabular}


Table 4. Vehicles in service, in which the operators are going to use tachographs upon the enforcement of the regulation

\begin{tabular}{|l|c|c|}
\hline Type of a vehicle and ownership & $\begin{array}{c}\text { With tachographs already installed } \\
\text { (thous. units) }\end{array}$ & $\begin{array}{c}\text { With tachographs to be installed } \\
\text { (thous. units) }\end{array}$ \\
\hline Freight vehicle (juridical person) & 9.1 & 3.7 \\
\hline Freight vehicle (physical person) & 1.3 & 0.9 \\
\hline Buses (juridical person) & 1.3 & 1.4 \\
\hline Total: & $\mathbf{1 1 . 7}$ & $\mathbf{6 . 0}$ \\
\hline
\end{tabular}

Table 5. Costs of tachograph installation to 6.0 thous. vehicles in service based on the operators' plans

\begin{tabular}{|l|c|}
\hline \multicolumn{1}{|c|}{ Type of a vehicle and ownership } & Cost of tachograph Installation (million Lt) \\
\hline Freight vehicle (juridical person) & 5.4 \\
\hline Freight vehicle (physical person) & 1.4 \\
\hline Buses (juridical person) & 0.8 \\
\hline \multicolumn{1}{|c|}{ Total: } & $\mathbf{7 . 6}$ \\
\hline
\end{tabular}

Table 6. Tachograph maintenance costs of 17.7 thous. of vehicles per year based on the operators' plans

\begin{tabular}{|l|c|}
\hline \multicolumn{1}{|c|}{ Type of a vehicle and ownership } & Tachograph maintenance costs per year (million Lt) \\
\hline Freight vehicle (juridical person) & 2.0 \\
\hline Freight vehicle (physical person) & 0.3 \\
\hline Buses (juridical person) & \\
\hline \multicolumn{1}{|c|}{ Total: } & 0.1 \\
\hline
\end{tabular}

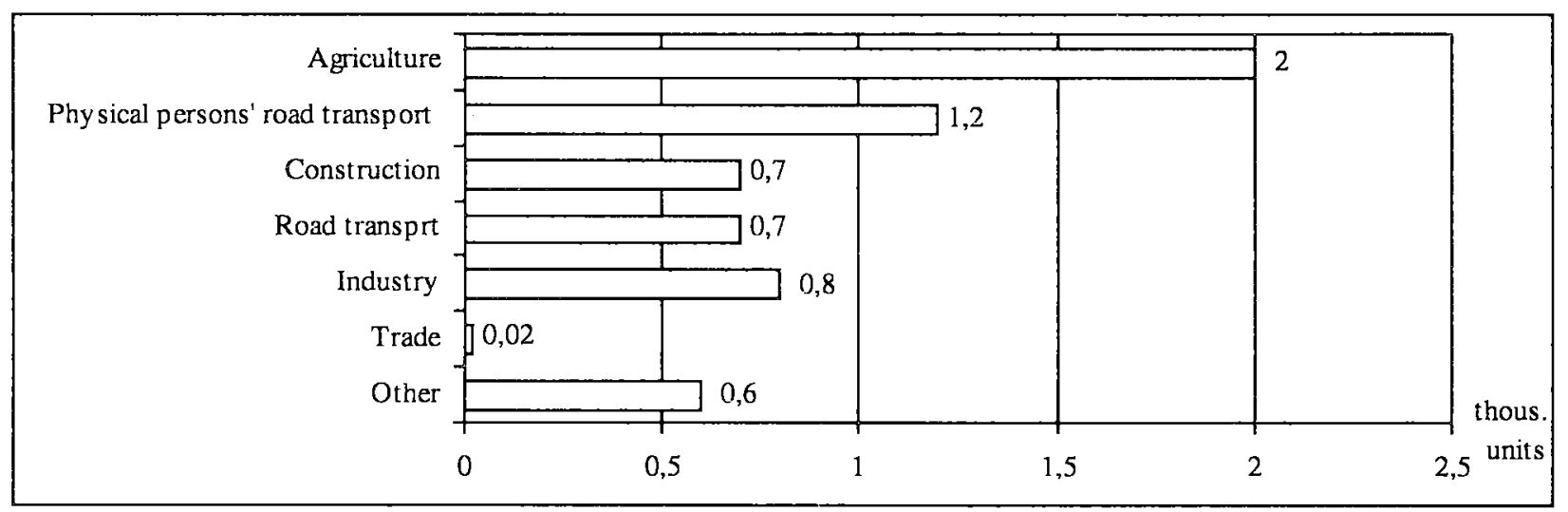

Fig 2. Distribution of vehicles, with tachographs to be installed, according to the type of operator's activity

posed on the final user, because:

- not all the operators on the national market will have to pay more, because the operators on international routes have already installed the tachographs and have been using them for some time now;

- buses are competing with illegal operators;

- more than one - third (38\%) of freight transport facilities operating on the inner routes are already equipped with tachographs.

\section{The Effect of Introducing Recording Devices in Road Transport on Macroeconomics}

Road vehicles transported about 44.4 million tons of 
cargo in 2000 . Local haul made $92 \%$ of all freight traffic based on weight (Table 7).

In 2000 local route vehicles had 333.4 million total kilometers logged. The expenses on tachograph installation and operation may raise local carriage cost by $1 \%$ $3 \%$. Therefore, it may be expected that the cost of tachograph introduction would not have much significance.

When the regulation 3821/85/EEC comes into force in Lithuania, tachographs will be mainly introduced in trade sector, agriculture, in road transport sector, in vehicles belonging to physical persons and construction (Fig 3).

In the above sectors the great portion of Common Inner Product (CIP) is usually created. Yearly expenses due to the additional use of tachographs will not exceed $0.01 \%$ of the created CIP in each of these sectors (Table 8) [10].

\section{Conclusions}

1. The enforcement of the Regulation 382 1/85/EEC in Lithuania will mainly affect three various interested parties: operators of transport facilities, state control bodies and institutions and organizations involved in the installation, selling, repair and control of tachographs.

2. At present about 37.8 thous. of vehicles are employed which will have to start operating tachographs when the regulation 3821/85/EEC comes into force. $38 \%$ of these transport facilities have the tachographs installed.

3. Installation of additional tachographs into 6.0 thous. of vehicles every year until Lithuania joins the EU will require 7.6 million Lt of investment in one time. Yearly expenses due to obligatory inspection and maintenance of 17.7 thous. of recording devices in transport will make 2.2 million $\mathrm{Lt}$.

Table 7. Distribution of cargoes transported by road vehicles in 1999 - 2000 (mil. tons) in Lithuania

\begin{tabular}{|l|l|l|}
\hline & 1999 & 2000 \\
\hline On local routes & 41.4 & 40.7 \\
\hline On international routes & 4.2 & 3.7 \\
\hline
\end{tabular}

Table 8. Common Inner Product (CIP) in various sectors of economy (current costs, millions Lt)

\begin{tabular}{|l|c|c|c|c|}
\hline & 1998 & 1999 & 2000 & $\begin{array}{c}\text { Specific weight, in } \\
2000, \%\end{array}$ \\
\hline CIP & 38034.9 & 38053.7 & 40674.2 & 100.0 \\
\hline Agriculture & 3888.4 & 3167.8 & 3070.3 & 7.5 \\
\hline Trade & 6207.5 & 5869.4 & 6137.9 & 15.1 \\
\hline Road transport & 1676.5 & 2378.1 & 2858.7 & 6.8 \\
\hline Construction & 3253.9 & 3023.9 & 2533.2 & 6.2 \\
\hline Industry & 2031.2 & 1871.2 & 2112.9 & 5.2 \\
\hline Other & 20977.4 & 21743.3 & 23461.2 & 59.1 \\
\hline
\end{tabular}

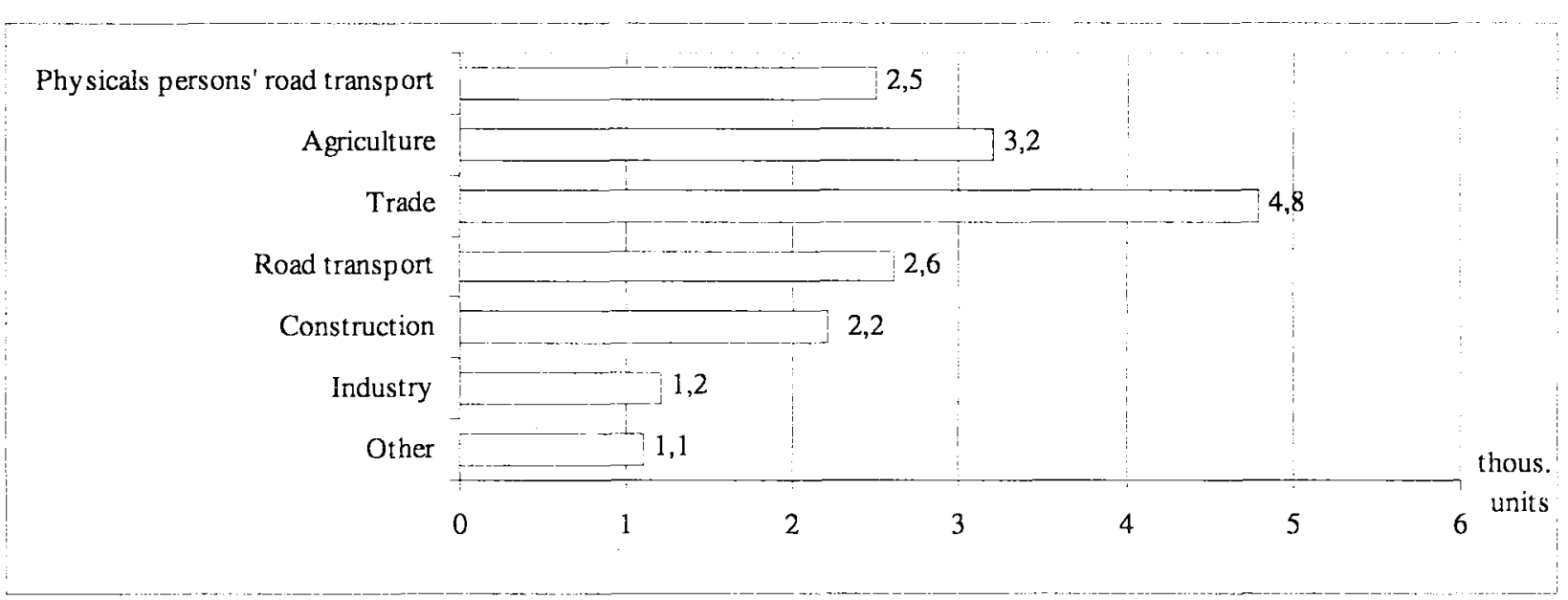

Fig 3. Distribution of vehicles in service in Lithuania, in which tachographs will be used, based on the type of activity 
4. City bus parks will be most severely affected, because their stock is heavily deteriorated and they are highly dependent on local authorities.

5. When the regulation $3281 / 85 / \mathrm{EEC}$ comes into force, the greatest amount of tachographs will be used in trade sector, agriculture, road transport, personal vehicles and construction.

6. A transition period of 4 years aimed to reduce adverse effects of enforcing the regulation on particular persons, sectors of economy or state - owned organizations, may be introduced.

7. Negative effect of enforcing the regulation is associated with the increased costs of inner road transportation, while a positive influence is based on the improved conditions of work and relaxation, less of accidents.

\section{References}

1. Regulation No 1-1532. On the Ratification of European States Agreement on Work Regulation of Road Vehicles Bound for International Routes (AETR) adapted in Lithuania on September 241996 (Lietuvos Respublikos $1996 \mathrm{~m}$. rugsèjo 24 d. istatymas Nr. I-1532, „Dèl Europos šalių susitarimo dèl keliu transporto priemonių ekipažu, važinèjančiu tarptautiniais maršrutais, darbo (AETR) ratifikavimo") (in Lithuanian).

2. Order No $126 / 44$ of the Ministers of Transportation and Governing Reforms and Municipality affairs "On tachographs using rules ratifity", issued in April 25, 2000 (Susisiekimo ir valdymo reformų ir savivaldybių reikalų ministrų $2000 \mathrm{~m}$. balandžio $25 \mathrm{~d}$. jsakymas Nr. 126/44 „Dèl tachografú naudojimo taisyklių patvirtinimo") (in Lithuanian).

3. Baublys A. International transportations by road transport (Tarptautiniai vežimai keliụ transportu). Vilnius: Technika, 1996. $185 \mathrm{p}$ (in Lithuanian).

4. Realization effects pf enforcing EU Regulation $3821 / 85$ EEC Europe Comitee of Lithuania Republic Goverment (Reglamento 3821/85 EEC igyvendinimo pasekmiu vertinimas). $2001.40 \mathrm{p}$ (in Lithuanian).

5. Accord europeen relatif au travail des equipages des vehicules effectuant des transports internationaux par route. AETR. Geneve. 19700701.13 p.

6. Mahdi Kamoun and Candace Arai Yano. Facility Layout to Support Just-in-Time. Transportation Science, Vol 30, No 4, 1996, p 315-329.

7. Prakash Mirchandani, Rajee Kohli and Arie Tomic. Capacitated Location Problems on a Line. Transportation Science, Vol 30, No 1, 1996, p 75 - 80 .

8. The datas base of state entertainment "Regitra" duomeny baze (VI „Registra“ duomenu bazè). 2001. 21 p (in Lithuanian).

9. The Study 2000 of cargos transportation by road transport Politice during integration of Lithuania to EU Lithuania Free Market Institute. 2000. 98 p (in Lithuanian).

10. Lithuanians macroeconomice review. Bank of Vilnius. April 2001 (Lietuvos makroelektroninė apžvalga. Vilniaus bankas). $32 \mathrm{p}$ (in Lithuanian). 